\title{
Biocontrol Fitness of an Indigenous Trichoderma viride, isolate NRCL T-01 against Fusarium solani and Alternaria alternata causing Diseases in Litchi (Litchi chinensis)
}

\author{
Vinod Kumar*, Ajit Kumar Dubedi Anal and Vishal Nath
}

ICAR-National Research Centre on Litchi, Mushahari, Muzaffarpur - 842002 (Bihar), India

*Corresponding author

\begin{tabular}{|c|}
\hline Key \\
\hline $\begin{array}{l}\text { Antagonist, Biocontrol, } \\
\text { Fusarium solani, Lychee, } \\
\text { Rhizosphere, } \\
\text { Trichoderma, Wilt }\end{array}$ \\
\hline Article Info \\
\hline $\begin{array}{l}\text { Accepted: } \\
\text { 24 February } 2018 \\
\text { Available Online: } \\
10 \text { March } 2018\end{array}$ \\
\hline
\end{tabular}

\section{Keywords}

Antagonist, Biocontrol, Trichoderma, Wilt

\section{A B S T R A C T}

Biological control represents an important approach to manage plant diseases. Blights of leaf, panicle and fruits caused by Alternaria alternata and the wilt caused by Fusarium solani are important diseases of litchi. Hence, as an alternative to chemical fungicides, biological control by Trichoderma spp. to manage pathogens of litchi was explored. The aim of this study was to isolate native Trichoderma spp. from litchi orchard ecosystem and to evaluate antagonistic potential and its biological fitness so as to develop a commercial formulation for field application to manage litchi diseases. The results showed that out of nine isolates of Trichoderma spp. isolated from litchi rhizosphere soil collected from different litchi orchards located in Muzaffarpur, Bihar the Trichoderma viride isolate NRCL T-01 showed highest antagonistic activity in dual culture bioassay against litchi pathogens, A. alternata (70.5\% inhibition) and $F$. solani $(60.9 \%$ inhibition). The volatile and non-volatile compounds produced by the isolate could effectively inhibit both the pathogens. It could grow well at temperature between 15 to $45{ }^{\circ} \mathrm{C}$, tolerated $\mathrm{pH}$ between 4.0 to 7.0 and high salt stress $(0.25-1.50 \mathrm{M} \mathrm{NaCl})$. The talc based formulation of the $T$. viride isolate NRCL T-01 effectively controlled litchi wilt pathogen $F$. solani on challenge inoculation in glasshouse condition as well as naturally affected litchi trees in orchards. Additionally, the isolate showed good plant growth promotion activity acting as a biofertilizer and helping air-layers to establish better in fields. Further study is being conducted to validate the potential as a commercially-viable product under farmers' field conditions.

\section{Introduction}

Litchi or Lychee (Litchi chinensis Sonn.) [Family Sapindaceae] is a tropical and subtropical fruit tree native to the Guangdong and Fujian provinces of China, and now cultivated in many parts of the world. Litchi is extensively grown in China, India, Thailand, Vietnam and the rest of tropical Southeast
Asia, the Indian Subcontinent (Papademetriou and Dent, 2002), and more recently in South Africa, Brazil, the Caribbean, Queensland, California and Florida (Crane et al., 2008). The acreage under litchi cultivation in India was 84,000 ha with a production of 585,000 tonnes during 2013-14 (NHB, 2016). Major litchi producing states in India are Bihar, West Bengal, Assam and Jharkhand. Bihar 
contributes $45 \%$ of total litchi production and has $40 \%$ of the acreage (Kumar et al., 2014). Fortunately, litchi is less affected by diseases than many other fruit trees in India. Among the economically important diseases of litchi in India are anthracnose ( $C$. gloeosporioides) and twig blight ( $C$. gloeosporioides and Gloeosporium sp.) at pre-harvest stage (Kumar et al., 2011, 2014), and fruit rots caused by several pathogens including Alternaria alternata, Aspergillus flavus, Cylindrocarpon tonkinense, $B$. theobromae and $C$. gloeosporioides at post-harvest stage (Awasthi et al., 2005; Kumar et al., 2016a, 2016b). Among the new challenges of diseases, blights of leaf, panicle and fruits caused by Alternaria alternata (Kumar et al., 2017) and the wilt caused by Fusarium solani (Kumar et al., 2011) are important. To manage pathogens of litchi, particularly Fusarium solani, biological control by Trichoderma spp. could be an effective alternative.

Trichoderma spp. are fungi that are present in nearly all soils and other diverse habitats. They are well-known biocontrol agents (BCAs) due to their ability to antagonize plant pathogens (Benítez et al., 2004; Harman, 2006), to induce plant defense responses against pathogens, with beneficial effects on plant growth and development (Harman et al., 2004), and also to improve photosynthetic efficiency and respiratory activity, by reprogramming plant gene expression (Shoresh et al., 2010). Many Trichoderma spp. antagonize phytopathogenic fungi through mycoparasitism (Lorito et al., 1996a), antibiosis (Ghisalberti and Sivasithamparam, 1991), enzyme production (Markovich and Kononova, 2003), and competition for resources (Sivan and Chet, 1989). In most cases, a single Trichoderma spp. isolate simultaneously employs more than one of these antagonistic mechanisms to suppress disease-causing fungi. Trichoderma spp. are avirulent symbionts that colonize the outermost epidermal layers of plant roots (Yedidia et al., 2000). During plant Trichoderma interaction, numerous elicitors released by the Trichoderma hyphae may induce different types of signals transmitted within the plant e.g. by salicylic acid, jasmonic acid or reactive oxygen species, triggering expression of defence proteins (Nawrocka and Małolepsza, 2013). Trichoderma spp. as antagonist has so far not been explored for management of litchi diseases in India. Hence, the aim of this study was to isolate native Trichoderma spp. from litchi orchard ecosystem and to evaluate antagonistic potential and its biological fitness so as to develop a commercial formulation for field application to manage litchi diseases.

\section{Materials and Methods}

\section{Isolation of pathogens}

Isolation of Fusarium solani was done from root bits of wilted litchi plants whereas Alternaria alternata was isolated from blighted leaves (Kumar et al., 2017). Diseased root bits were washed under running tap water to remove surface soil and other contaminant. Isolations of both the fungi were made by surface-disinfesting small fragments of symptomatic root and leaf tissues in $0.5 \%$ $\mathrm{NaOCl}$, double-rinsing in sterile water, and plating onto potato dextrose agar (PDA) amended with $0.05 \mathrm{~g} \quad \mathrm{~L}^{-1}$ streptomycin sulphate. Plates were incubated at $28 \pm 1{ }^{\circ} \mathrm{C}$ for 6 days and pure cultures were obtained using the hyphal tip method.

\section{Isolation of Trichoderma sp.}

Twenty random rhizosphere soil samples were collected from different litchi orchards located in Muzaffarpur, Bihar and stored in plastic bags. The soil samples were air dried and isolation was done following the serial dilution technique on Trichoderma selective 
medium (Elad et al., 1981). Morphologically distinct colonies were picked on the basis of their morphology (Kubicek and Harman, 1998) and purified on PDA following subculturing.

\section{Antagonistic activity of Trichoderma isolates}

The dual culture technique (Cherif and Benhamou, 1990) was used to test the antagonistic ability of Trichoderma sp. against two fungal pathogens of litchi namely $A$. alternata and $F$. solani. A $5 \mathrm{~mm}$ mycelia disc of both the fungi (Trichoderma sp. and phytopathogenic test fungus) cut from the periphery were placed aseptically on PDA plate about $2.0-2.5 \mathrm{~cm}$ away from each other. The plates were incubated at $28 \pm 1^{\circ} \mathrm{C}$ for 7 days and observed periodically. The experiment was conducted under Completely Randomized Design (CRD). The experiment was replicated thrice and the growth of the pathogen in both test and control experiments were recorded. Percent inhibition of radial growth (PIRG) was calculated by the formula: PIRG $=(\mathrm{C}-\mathrm{T}) / \mathrm{C} \times 100$, where $\mathrm{C}=$ radial growth of pathogen in control plate, and $\mathrm{T}=$ radial growth of pathogen in dual culture with Trichoderma sp. (Kumar et al., 2012). Trichoderma viride strain NRCG T-09, isolated from groundnut crop rhizosphere, obtained from Directorate of Groundnut Research, Junagadh, Gujarat was used as reference strain for comparison of antagonistic activity.

\section{Pathogen inhibition through non-volatile inhibitors of Trichoderma}

The effect of non-volatile metabolites on pathogen was studied following the method of Dennis and Webster (1971) and Jash and Pan (2007). Different antagonists were cultured in $100 \mathrm{~mL}$ sterile potato dextrose broth in 250 $\mathrm{mL}$ Erlenmeyer flask with intermittent shaking. After 10 days, the culture filtrate was passed through Whatman No. 42 filter paper and the filtrate was collected in sterile Erlenmeyer flasks. The culture filtrate was centrifuged at $3000 \mathrm{rpm}$ for $10 \mathrm{~min}$ and sterilized by passing through millipore membrane filter paper $(0.4 \mu \mathrm{m}$ pore size $)$. Different volumes of filtrates were added to the molten PDA medium to obtain final concentrations of 5 and $10 \%(\mathrm{v} / \mathrm{v})$. The medium was poured into Petri plate and inoculated with mycelial plug of pathogen from 4-day old colonies. The Petri plates were incubated at $28 \pm 1{ }^{\circ} \mathrm{C}$ for 7 days. Control plates were maintained without culture filtrate. Radial mycelial growth of the pathogen (colony diameter) was measured at right angles to each other and the inhibition percentage calculated.

\section{Pathogen inhibition through volatile metabolites of Trichoderma}

The effect of volatile metabolites produced by the antagonistic microorganisms on pathogens' mycelial growth was determined following the method described by Dennis and Webster (1971) and Schwarze et al., (2012).

The Trichoderma viride was centrally inoculated by placing $5 \mathrm{~mm}$ mycelial disc taken from 7-day-old culture onto the PDA plate and incubated at $28 \pm 1^{\circ} \mathrm{C}$ for 4 days. Other PDA plates were inoculated centrally with 5-mm disc of pathogen culture.

Then the top of each Trichoderma-inoculated plate was replaced with bottom of the PDA plate inoculated with the pathogen. Two plates were sealed together with paraffin tape and further incubated at $28 \pm 1^{\circ} \mathrm{C}$. Replicates without Trichoderma (having $5 \mathrm{~mm}$ of sterile PDA medium disc) were used as the control.

Colonies diameter of the pathogen was measured after 5 and 7 days, and the inhibition of mycelia growth was calculated.

Tolerance to temperature 
The ability of NRCL Trichoderma viride isolate NRCL T-01 to grow at different temperature was assessed by growing the cultures on PDA plates and incubating them at $15,20,25,30,35,40,45$ and $50{ }^{\circ} \mathrm{C}$. Trichoderma sp. was inoculated in triplicates at the centre of $90 \mathrm{~mm}$ PDA plates by placing $5-\mathrm{mm}$ mycelial discs from the margin of colonies. The plates were incubated at different temperature and the radial growth was measured (in $\mathrm{mm}$ ) everyday up to 7 days of inoculation.

\section{Tolerance to $\mathrm{pH}$}

Different $\mathrm{pH}$ used for the study was 4, 5, 6, 7, 8 and 9. One hundred mL PDA media were prepared in triplicates and its $\mathrm{pH}$ was adjusted by adding $\mathrm{HCl}$ or $\mathrm{NaOH}$ before autoclaving. Disc of fungal culture was inoculated on the plates and measurement of the radial mycelia growth and sporulation were recorded.

\section{Tolerance to salt concentration}

The effect of $\mathrm{NaCl}$ was tested on growth of NRCL Trichoderma viride isolate NRCL T-01 cultured on PDA medium. PDA was amended with $\mathrm{NaCl}$ at $0.25 \mathrm{M}, 0.50 \mathrm{M}, 0.75 \mathrm{M}, 1.00 \mathrm{M}$, $1.25 \mathrm{M}$ and $1.50 \mathrm{M}$ concentrations and 5-mm mycelial disc was inoculated in each plate and incubated at $28^{\circ} \mathrm{C}$. The diameter of colonies was measured at 24 hour interval up to 7 days.

\section{Evaluation of Trichoderma sp. against litchi wilt under glasshouse and field conditions}

For evaluation under glasshouse, rhizosphere soil of one year old potted air-layered litchi plants were inoculated with the pure culture of $F$. solani and talc based formulation of $T$. viride isolate NRCL T-01 (having $2 \times 10^{6}$ cfu/g). Fifty gram talc formulation of $T$. viride was applied on top soil and mixed. $F$. solani was inoculated by adopting toothpick inoculation technique as described by Keeling (1982). Plants were inoculated by inserting toothpick tip overgrown with mycelia of $F$. solani. Five tooth pick per plant was inoculated near the rhizosphere of the plant. Trichoderma was applied 3 days prior to inoculation of $F$. solani. Five plants inoculated with $F$. solani only served as control.

For evaluation under field conditions, trees of different age in the orchards, affected presumably by wilt pathogen $F$. solani at various times were chosen. A talc based formulation of Trichoderma viride isolate NRCL T-01 (having $2 \times 10^{6} \mathrm{cfu} / \mathrm{g}$ ) was applied @ 100-200 g per tree depending on age $(<5$ year old @100 g/tree and >5 year old @ 200 $\mathrm{g} /$ tree). The days to recovery of trees and population count (cfu) of Trichoderma in the rhizosphere soil was monitored. Trichoderma was added to the soil along with vermicompost $(5 \mathrm{~kg}$ for bearing trees and for juvenile trees about 2-4 kg/tree) as a food substrate.

\section{Statistical analysis}

The data were analyzed using SAS $^{\circledR} 9.2$ statistical computing software and subjected to analysis of variance (ANOVA). The least significant differences (LSD) between means were computed at 5\% significance level $(\mathrm{P}<$ $0.05)$.

\section{Results and Discussion}

\section{Isolation and identification of pathogens}

Fungi isolated from root bits of wilted litchi plants produced fast growing, white and cottony colony on PDA medium. They slightly curved, thick walled macroconidia having 3-4 septa, and had a slightly blunted apical end. Microconidia were oval to kidney shaped, and formed in false heads on very long monophialides. Chlamydospores were 
abundant (Fig. 1). Based on these morphocultural characteristics, pathogen was identified as Fusarium solani that was also confirmed by a former mycologist, Indian Type Culture Collection, New Delhi.

Similarly, fungi isolated from blighted litchi leaves was identified as Alternaria alternata based on morpho-cultural characteristics such as grey to black colonies; branched, brownish, septate mycelia and dark brown, obclavate to obpyriform, catenulate conidia borne on short conidiophores.

\section{Isolation of Trichoderma spp. and dual culture bioassay}

Nine isolates of Trichoderma spp. were obtained from a total of 20 litchi rhizosphere soil samples collected from different litchi orchards located in Muzaffarpur, Bihar. All the isolates showed antifungal antagonistic activity in dual culture bioassay against litchi pathogens, Alternaria alternata and Fusarium solani. The isolate of Trichoderma viride NRCL T-01, isolated from NRCL Farm was found to be the most efficient isolate in controlling both $A$. alternata and $F$. solani under in-vitro condition (Fig. 2) as compared to eight other isolates of Trichoderma spp. (Table 1). PIRG of colony of pathogens by different isolate of Trichoderma spp. varied from 41.0 to 70.5 . The maximum inhibition of colony growth of A. alternata in dual culture was $70.5 \%$ by the isolate NRCL T-01 and the biocontrol agent completely overgrew the pathogen in 8 days. Similarly, the maximum inhibition of colony growth of $F$. solani (60.9\%) was by the isolate NRCL T-01 and within 6 days, it completely overgrew the pathogen. Thus, the isolate NRCL T-01 was selected for further assay for biological fitness. The results showed that isolate NRCL T-01 could restrict the growth of phytopathogens of litchi in dual culture which prove its efficacy in management of diseases incited by them. The antagonistic activity of Trichoderma depends on multiple synergistic mechanisms (Nallathambi et al., 2009; Howell, 2003). The various mechanisms include antibiosis, parasitism, inducing hostplant resistance, competition and secretion of chitinolytic enzymes, mycoparasitism and production of inhibitory compounds (Harman et al., 2004).

\section{Pathogen inhibition through volatile metabolites of Trichoderma}

The results revealed that in presence of volatile metabolites produced by $T$. viride, radial mycelia growth of the pathogens viz., A. alternata and $F$. solani were slower than in control (Fig. 3 and 4). Overall growth rate of A. alternata after six days of incubation was $8.8 \mathrm{~mm} /$ day in presence of the isolate NRCG $\mathrm{T}-09$ and $6.6 \mathrm{~mm} /$ day in the presence of the isolate NRCL T-01 of T. viride as compared to $11.7 \mathrm{~mm} /$ day in control plates. Similarly, growth rate of $F$. solani after six days of incubation was $14.0 \mathrm{~mm} /$ day in presence of the isolate NRCG T-09 and $11.9 \mathrm{~mm} /$ day in the presence of isolate NRCL T-01 of $T$. viride as compared to $21.5 \mathrm{~mm} /$ day in control plates. The data also showed that after 6 day of incubation, there was $24.86 \%$ inhibition of growth of A. alternata by the $T$. viride isolate NRCG T-09, whereas it was $43.28 \%$ by the isolate NRCL T-01. Likewise, after 4 days of incubation, an inhibition of $20.93 \%$ in growth of $F$. solani by the isolate NRCG T-09 and $40.69 \%$ by the isolate NRCL T-01 was apparent. Thus, results clearly showed the superiority of the local strain NRCL T-01 over NRCG T-09 in controlling both the pathogens of litchi. There is large variety of volatile secondary metabolites produced by Trichoderma such as ethylene, hydrogen cyanide, aldehydes and ketones which play an important role in controlling the plant pathogens (Vey et al., 2001). 
Fig.1 Asexual spores (microconidia and macroconidia) of Fusarium solani

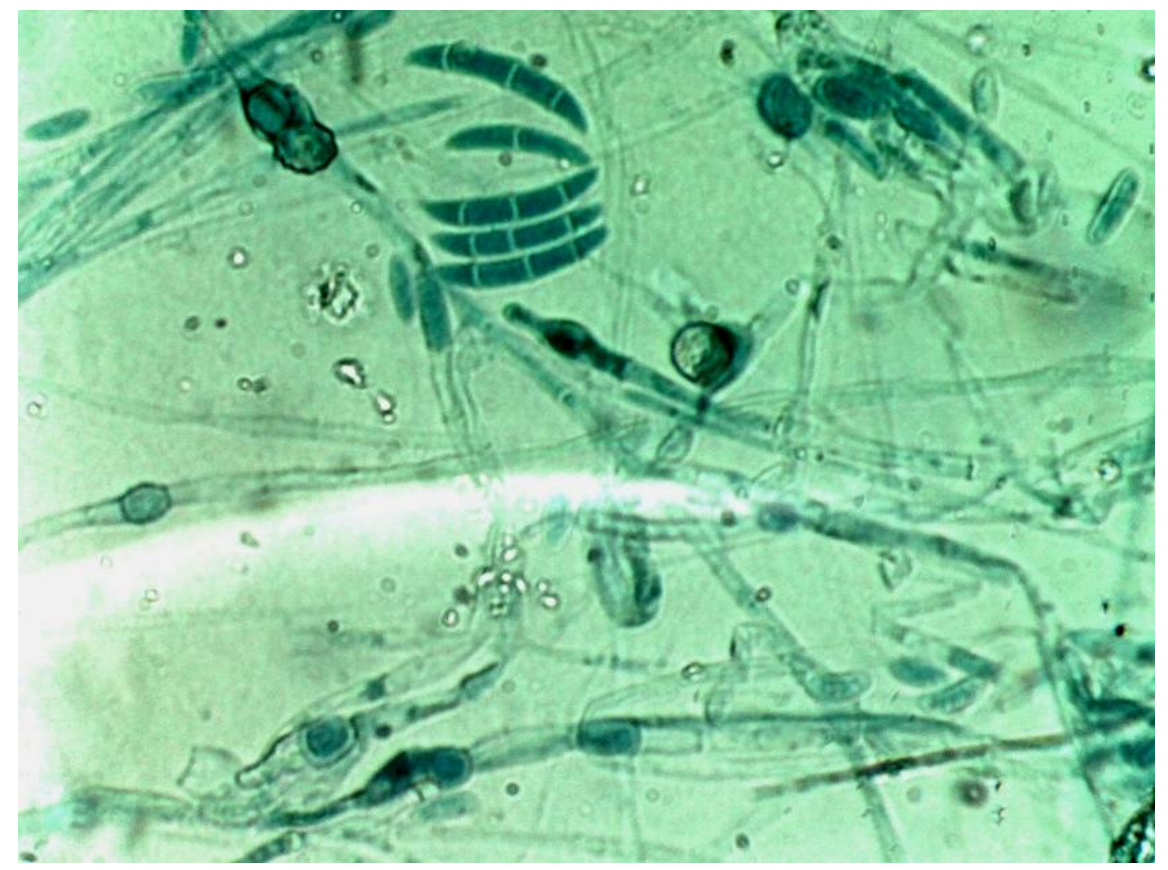

Fig.2 In vitro antifungal activity of the Trichoderma viride strain NRCL T-01 against $A$. alternata (A, B) and $F$. solani (C, D) on PDA plates

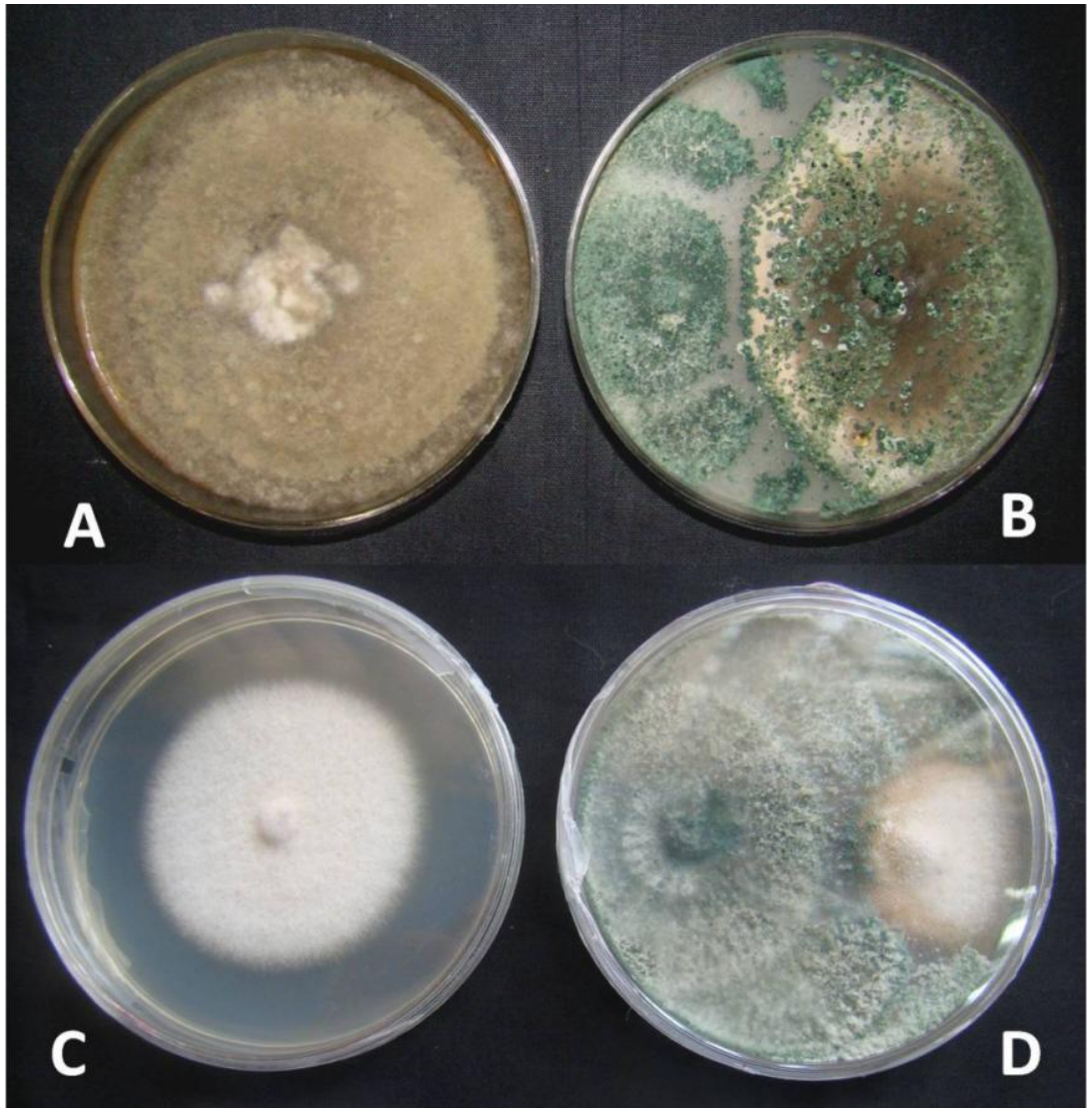


Fig.3 Radial mycelia growth of Alternaria alternata in the presence of volatile metabolites emitted by Trichoderma vride. The vertical bar indicates standard error (SE) of the means

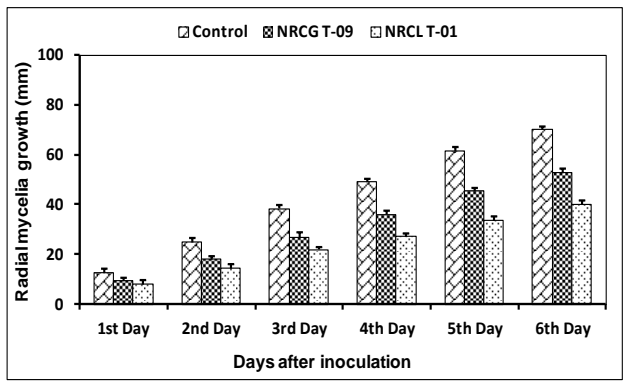

Fig.4 Radial mycelia growth of Fusarium solani in the presence of volatile metabolites emitted by Trichoderma vride. The vertical bar indicates standard error (SE) of the mean

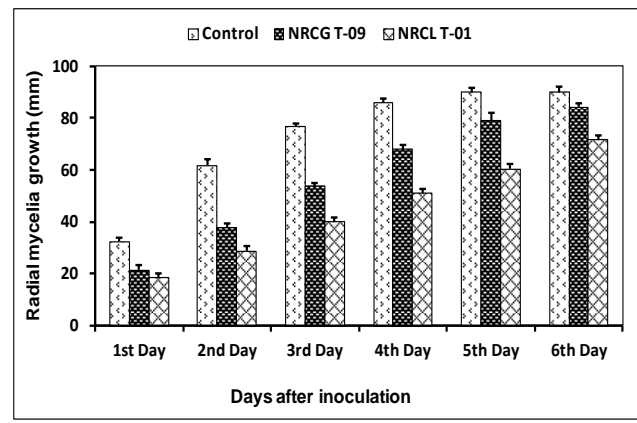

Fig.5 Effect of non-volatile compounds produced by Trichoderma viride isolate NRCL T-01 on growth of Alternaria alternata

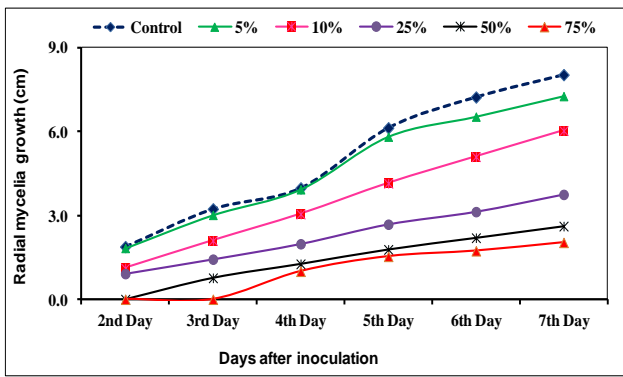

Fig.6 Effect of non-volatile compounds produced by Trichoderma viride isolate NRCL T-01 on growth of Fusarium solani

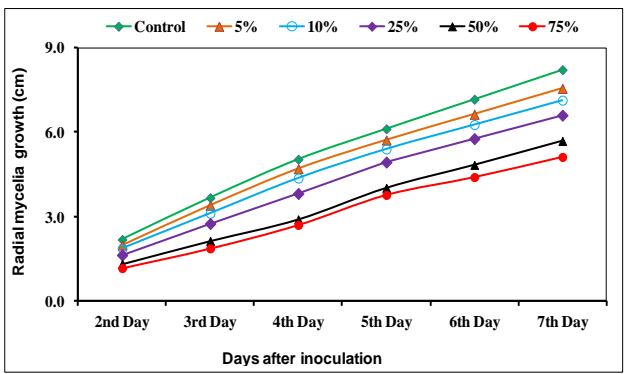


Fig.7 Effect of non-volatile compounds produced by Trichoderma viride isolate NRCG T-09 on growth of Alternaria alternata

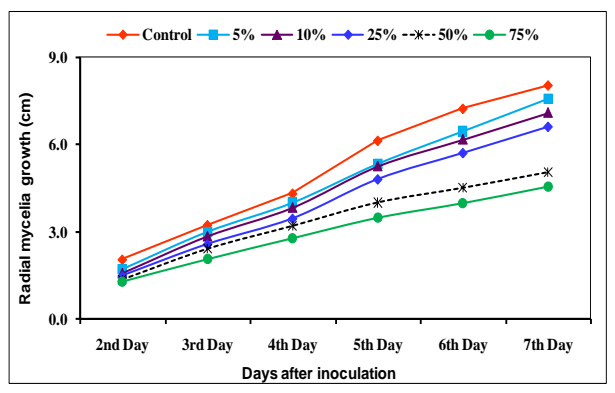

Fig.8 Effect of non-volatile compounds produced by Trichoderma viride isolate NRCG T-09 on growth of Fusarium solani

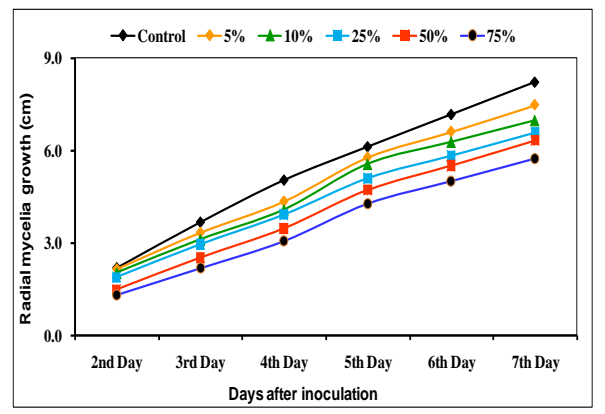

Fig.9 Growth of Trichoderma viride isolate NRCL T-01 at different temperatures

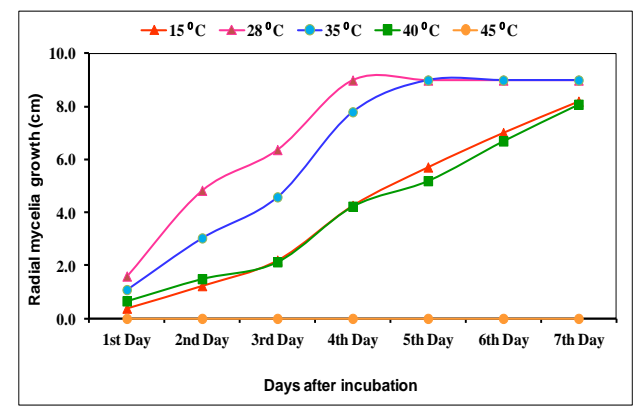

Fig.10 Radial mycelia growth of Trichoderma viride isolate NRCL T-01 at different NaCl salt concentration

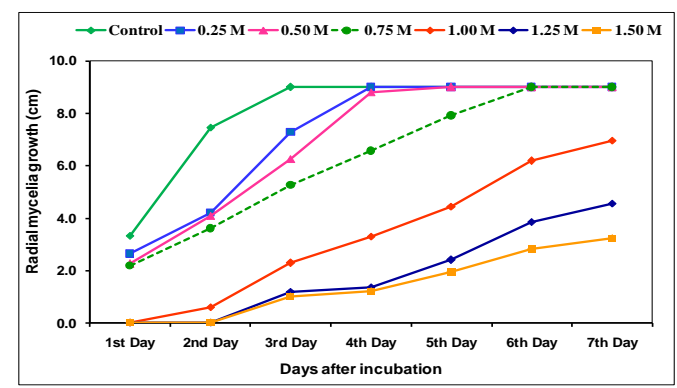


Fig.11 Growth and colony morphology of Trichoderma viride isolate NRCL T-01 at different $\mathrm{NaCl}$ salt concentration (Left to right: Top row- Control, $0.25 \mathrm{M}, 0.50 \mathrm{M}, 0.75 \mathrm{M}$;

Bottom row-1.0 M, 1.25 M, 1.50 M)

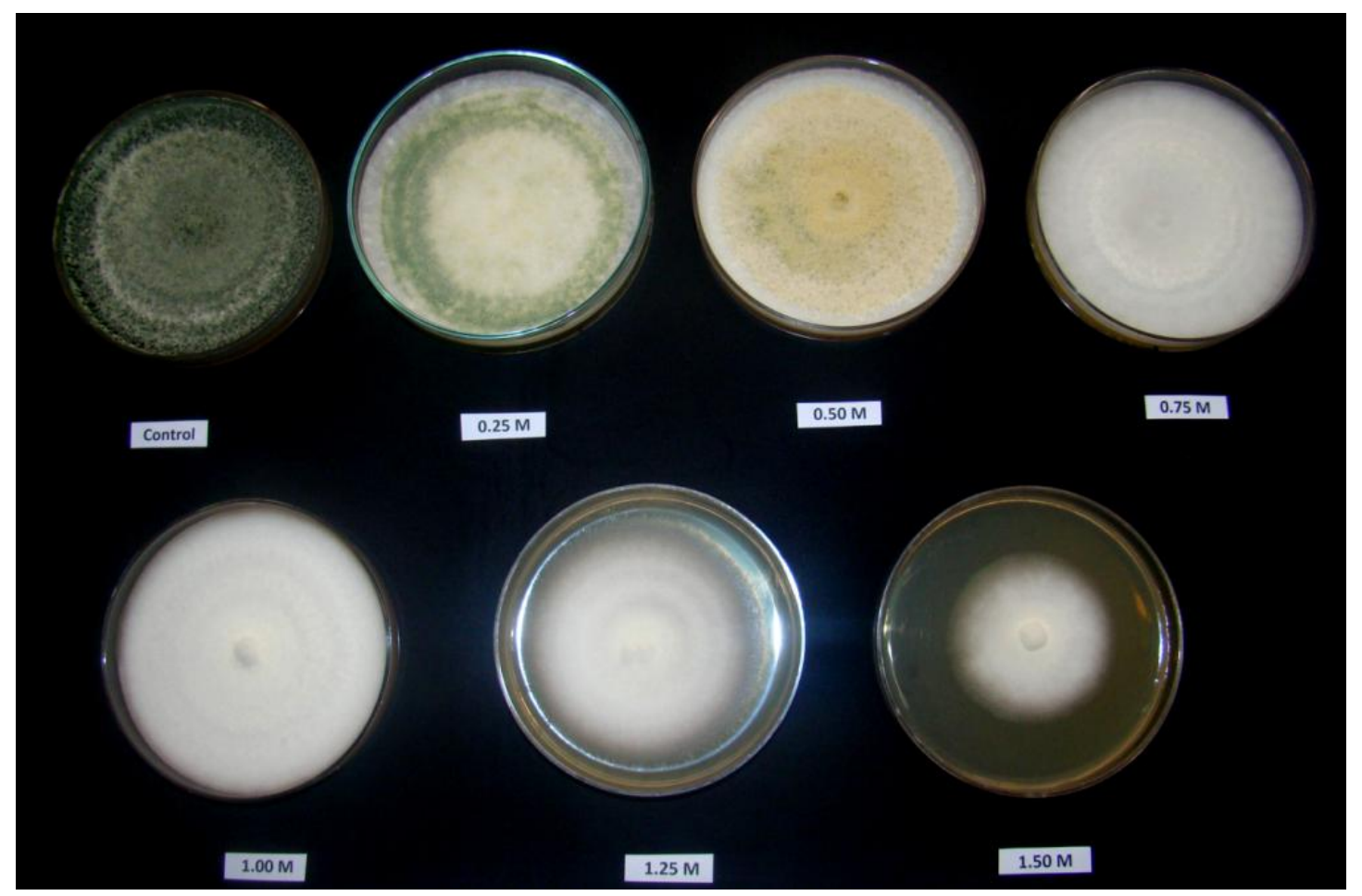

Fig.12 A litchi tree showing symptoms of wilt (Left) and condition of the tree following recovery due to application of Trichoderma (T. viride isolate NRCL T-01) at the NRCL experimental farm (Right)

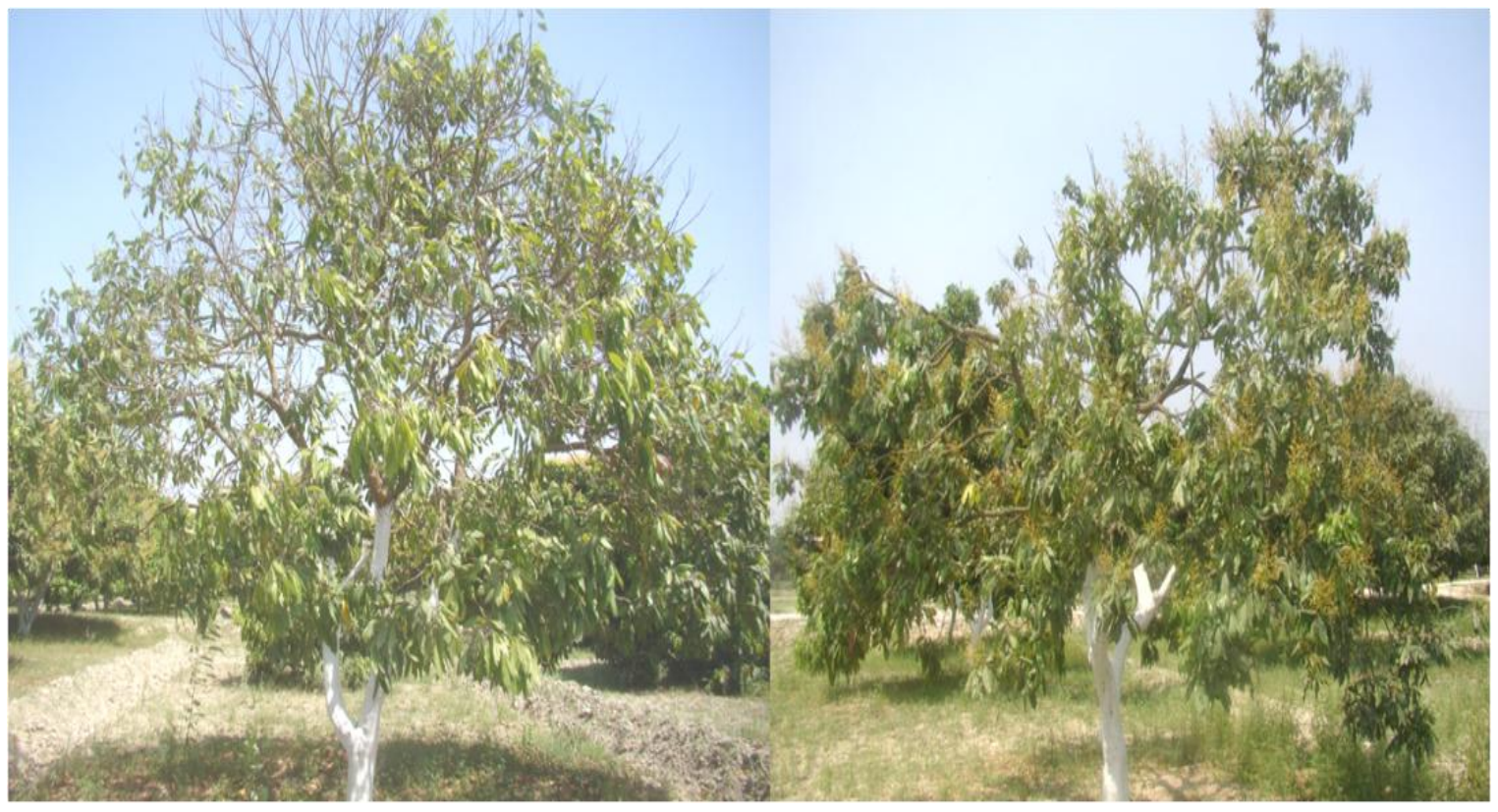


Table.1 Antagonistic activity of isolates of Trichoderma spp. against Alternaria alternata and Fusarium solani in dual culture bioassay

\begin{tabular}{|c|c|c|c|c|c|c|c|c|}
\hline \multirow{2}{*}{$\begin{array}{l}\text { S. } \\
\text { No. }\end{array}$} & \multirow[t]{2}{*}{ Isolate No. } & \multirow[t]{2}{*}{ Trichoderma species } & \multicolumn{3}{|c|}{ Alternaria alternata } & \multicolumn{3}{|c|}{ Fusarium solani } \\
\hline & & & $\begin{array}{l}\text { Radial growth in } \\
\text { dual culture* }(\mathrm{T})\end{array}$ & PIRG & $\begin{array}{c}\text { Time taken } \\
\text { to } \\
\text { completely } \\
\text { overgrow } \\
\text { the } \\
\text { pathogen }\end{array}$ & $\begin{array}{l}\text { Radial growth in } \\
\text { dual culture* } \\
\text { (T) }\end{array}$ & PIRG & $\begin{array}{c}\text { Time taken } \\
\text { to } \\
\text { completely } \\
\text { overgrow } \\
\text { the pathogen }\end{array}$ \\
\hline 1. & NRCL T-01 & Trichoderma viride & 20.7 & 70.5 & 8 & 34.7 & 60.9 & 6 \\
\hline 2. & NRCL T-02 & Trichoderma harzianum & 31.7 & 54.8 & 10 & 47.3 & 46.6 & 9 \\
\hline 3. & NRCL T-03 & Trichoderma harzianum & 31.3 & 55.2 & 12 & 49.7 & 44.0 & 11 \\
\hline 4. & NRCL T-04 & Trichoderma viride & 33.0 & 52.9 & 11 & 46.3 & 47.7 & 9 \\
\hline 5. & NRCL T-05 & Trichoderma viride & 36.3 & 48.1 & 14 & 47.0 & 47.0 & 12 \\
\hline 6. & NRCL T-06 & Trichoderma viride & 39.7 & 43.3 & 12 & 50.0 & 43.6 & 12 \\
\hline 7. & NRCL T-07 & Trichoderma viride & 32.3 & 53.8 & 10 & 47.7 & 46.2 & 9 \\
\hline 8. & NRCL T-08 & Trichoderma virens & 30.0 & 57.1 & 13 & 47.7 & 46.2 & 10 \\
\hline \multirow[t]{5}{*}{9.} & NRCL T-09 & $\begin{array}{l}\text { Trichoderma } \\
\text { pseudokoningii }\end{array}$ & 41.0 & 41.4 & 14 & 49.7 & 44.0 & 12 \\
\hline & NRCG T-09 & Trichoderma viride & 40.0 & 42.9 & 14 & 52.3 & 41.0 & 11 \\
\hline & Control (C) & - & 70.0 & 0.0 & & 88.7 & 0.0 & \\
\hline & $\begin{array}{c}\text { LSD } \\
(\mathrm{p}<0.05)\end{array}$ & & 2.72 & & & 2.57 & 60.9 & \\
\hline & $\operatorname{SEm}( \pm)$ & & 0.92 & & & 0.87 & 46.6 & \\
\hline
\end{tabular}

$\mathrm{C}=$ Radial growth of pathogen in control plate (monoculture), $\mathrm{T}=$ Radial growth of pathogen in dual culture with Trichoderma sp., PIRG= Percent inhibition of radial growth; * Mean radial growth after 6 days of incubation. NRCG T-09 obtained from Directorate of Groundnut Research, Junagadh, Gujarat was used as reference strain for comparison. 
Table.2 Effect of different $\mathrm{pH}$ on radial mycelia growth of the two isolates of Trichoderma viride incubated at $28{ }^{\circ} \mathrm{C}$

\begin{tabular}{|c|c|c|c|c|c|c|}
\hline \multirow{2}{*}{ pH } & \multicolumn{6}{|c|}{ Mean radial mycelia growth (cm) } \\
\cline { 2 - 8 } & \multicolumn{2}{|c|}{ After 24 hr } & \multicolumn{2}{c|}{ After 48 hr } & \multicolumn{2}{c|}{ After $72 \mathrm{hr}$} \\
\hline & NRCL T- & NRCG T- & NRCL T- & NRCG T- & NRCL T- & NRCG T- \\
& 01 & 09 & 01 & 09 & 01 & 09 \\
\hline $\mathbf{4 . 0}$ & 1.92 & 1.37 & 5.70 & 4.88 & 8.50 & 7.63 \\
\hline $\mathbf{5 . 0}$ & 1.72 & 1.18 & 5.40 & 4.87 & 8.70 & 7.70 \\
\hline $\mathbf{6 . 0}$ & 1.95 & 1.88 & 4.93 & 5.97 & 8.87 & 8.49 \\
\hline $\mathbf{7 . 0}$ & 2.02 & 1.58 & 5.72 & 5.73 & 8.97 & 8.50 \\
\hline $\mathbf{8 . 0}$ & 1.57 & 1.56 & 4.90 & 5.25 & 8.73 & 8.47 \\
\hline $\mathbf{9 . 0}$ & 1.38 & 1.54 & 5.03 & 5.47 & 8.67 & 7.70 \\
\hline LSD (p<0.05) & 0.27 & 0.30 & 0.46 & 0.70 & NS & 0.52 \\
\hline SEm $( \pm)$ & 0.09 & 0.10 & 0.15 & 0.23 & 0.10 & 0.17 \\
\hline
\end{tabular}

*NS= Non-significant

Table.3 Effect of application of Trichoderma viride on litchi trees affected by wilt and its population dynamics at NRCL Experimental Farm, Muzaffarpur during 2015-2017

\begin{tabular}{|c|c|c|c|c|c|c|c|c|}
\hline \multirow[t]{2}{*}{$\begin{array}{c}\text { Tre } \\
\text { e } \\
\text { no. }\end{array}$} & \multirow[t]{2}{*}{$\begin{array}{l}\text { Age } \\
\text { of the } \\
\text { tree }\end{array}$} & \multirow[t]{2}{*}{ Cultivar } & \multirow[t]{2}{*}{$\begin{array}{l}\text { Tree conditions before } \\
\text { application }\end{array}$} & \multirow{2}{*}{$\begin{array}{c}\text { Time } \\
\text { taken for } \\
\text { complete } \\
\text { recovery } \\
\text { (days) }\end{array}$} & \multicolumn{4}{|c|}{$\begin{array}{c}\text { Population of Trichoderma sp. } \\
\text { in rhizosphere } \\
\left(10^{3} \mathrm{cfu} / \mathrm{g} \text { of soil }\right)\end{array}$} \\
\hline & & & & & 0 day & $\begin{array}{l}15 \\
\text { day }\end{array}$ & $\begin{array}{l}30 \\
\text { day }\end{array}$ & $\begin{array}{l}45 \\
\text { day }\end{array}$ \\
\hline 1 & 10 & 'Shahi' & $\begin{array}{l}\text { Yellowing and drooping } \\
\text { of leaves }\end{array}$ & 25 & 6.67 & 19.33 & 38.00 & 27.91 \\
\hline 2 & 15 & ‘Shahi' & $\begin{array}{l}\text { Tree decline, yellowing } \\
\text { and drooping of leaves }\end{array}$ & 30 & 4.30 & 15.07 & 37.33 & 28.83 \\
\hline 3 & 5 & ‘China' & Tree decline & 25 & 5.00 & 13.02 & 30.99 & 27.91 \\
\hline 4 & 6 & ‘Shahi' & $\begin{array}{l}\text { Early symptoms of tree } \\
\text { wilting }\end{array}$ & 20 & 5.63 & 15.99 & 32.86 & 28.83 \\
\hline 5 & 5 & 'China' & $\begin{array}{l}\text { Early symptoms of tree } \\
\text { wilting }\end{array}$ & 20 & 5.86 & 25.81 & 34.97 & 30.99 \\
\hline 6 & 13 & 'Shahi' & $\begin{array}{l}\text { Tree decline, partial } \\
\text { wilting }\end{array}$ & 35 & 4.90 & 23.16 & 42.86 & 35.33 \\
\hline 7 & 2 & 'China' & $\begin{array}{l}\text { Yellowing and drooping } \\
\text { of leaves, stunted growth }\end{array}$ & 20 & 6.47 & 18.62 & 34.97 & 27.91 \\
\hline 8 & 4 & ‘Shahi’ & $\begin{array}{l}\text { Yellowing and drooping } \\
\text { of leaves, stunted growth }\end{array}$ & 20 & 2.10 & 22.38 & 60.53 & 48.83 \\
\hline 9 & 6 & ‘Shahi' & $\begin{array}{l}\text { Early symptoms of tree } \\
\text { wilting }\end{array}$ & 25 & 5.07 & 19.33 & 37.91 & 30.99 \\
\hline 10 & 12 & 'Shahi' & $\begin{array}{l}\text { Tree decline, partial } \\
\text { wilting }\end{array}$ & 30 & 3.67 & 19.67 & 35.33 & 32.86 \\
\hline
\end{tabular}




\section{Pathogen inhibition through non-volatile metabolites of Trichoderma}

Production of non-volatile compounds inhibitory to pathogens is one of the multiple modes of action of Trichoderma spp. In vitro antagonistic activity of culture filtrates of isolate NRCL T-01 significantly and variably reduced the radial colony growth of test pathogen.

It was observed that all concentration of culture filtrates had strong inhibitory effect but the highest inhibition of pathogen was observed at a concentration of $75 \%$ liquid culture filtrate where the isolate NRCL T-01 could inhibit growth of $A$. alternata up to $74.7 \%$ (radial mycelia growth in treatment $2.03 \mathrm{~cm}$ in contrast to $8.03 \mathrm{~cm}$ in control) and $37.71 \%$ of growth of Fusarium solani (radial mycelia growth in treatment $5.12 \mathrm{~cm}$ in contrast to $8.22 \mathrm{~cm}$ in control) (Fig. 5 and 6). No further increase in growth of the pathogen was observed till $15^{\text {th }}$ day of incubation.

In contrast to this, the isolate NRCG T-09 could inhibit growth of $A$. alternata up to $43.58 \%$ (radial mycelia growth in treatment $4.53 \mathrm{~cm}$ in contrast to $8.03 \mathrm{~cm}$ in control) and $30.29 \%$ of growth of Fusarium solani (radial mycelia growth in treatment $5.73 \mathrm{~cm}$ in contrast to $8.22 \mathrm{~cm}$ in control) (Fig. 7 and 8).

Our results corroborate the findings of Waseem et al., (2013) who reported that nonvolatile antifungal compounds extracted from the liquid culture of Trichoderma strain SQRT037 significantly inhibited the growth of $F$. oxysporum. f. sp. niveum which causes wilt of watermelon.

The experimental results of these studies viz. dual culture assay, production of volatile and non-volatile metabolites by the indigenous local isolate of Trichoderma viride NRCL T01 thus have proved its antagonistic potential.
This was further tested for tolerance to different temperature regime, $\mathrm{pH}$ and salt concentrations to assess its biological fitness under in-vitro conditions.

\section{Tolerance to temperature}

The T. viride isolate NRCL T-01 exhibited both high and low temperature tolerance though the radial mycelia growth rate varied at different temperature regimes. Studies showed that after four days of incubation at $15{ }^{\circ} \mathrm{C}$, radial mycelia growth was $9.0 \mathrm{~cm}$ at 28 ${ }^{\circ} \mathrm{C}$ while it was only $4.27 \mathrm{~cm}$ at $15{ }^{\circ} \mathrm{C}$ and $4.23^{\circ} \mathrm{C}$ at $40^{\circ} \mathrm{C}$ (Fig. 9). The highest growth rate was observed at $28{ }^{\circ} \mathrm{C}$ (overall growth rate $1.29 \mathrm{~cm}$ per day) and lowest at $40^{\circ} \mathrm{C}$ (overall growth rate $1.15 \mathrm{~cm}$ per day). Both increase and decrease in temperature from $28^{\circ} \mathrm{C}$ resulted in a decrease in radial mycelia growth. No colony growth was observed at $45^{\circ} \mathrm{C}$. Poosapati et al., (2014) reported that $T$. asperellum, TaDOR673 was able to survive and germinate normally at $28^{\circ} \mathrm{C}$ and survived through adverse temperature stress conditions. Petrisor et al., (2016) also reported that growth of $T$. viride strain Td50 was better at 25-30 ${ }^{\circ} \mathrm{C}$ and very slow at $15^{\circ} \mathrm{C}$.

\section{Tolerance to $\mathrm{pH}$}

Results indicated that both the isolates of $T$. viride developed at all the $\mathrm{pH}$ examined (4.07.0) however, variation in radial mycelia growth was apparent between isolates and between $\mathrm{pH}$ values. Observations made at 24 $\mathrm{hr}$ interval after incubation at $28 \pm 1{ }^{\circ} \mathrm{C}$ revealed that growth of both the isolates were significantly higher between $\mathrm{pH}$ 6.0-7.0 (Table 2). This result corroborates with the findings of Bitton and Boylan (1985) and Limón et al., (2004) who reported that acidic $\mathrm{pH}$ favoured fungal growth than alkaline $\mathrm{pH}$ and they modify the rhizosphere soil by acidifying the soil. This explains the reason for isolates which prefer acidic $\mathrm{pH}$. However, 
our isolate of $T$. viride, NRCL T-01 could grow well in a wide range of $\mathrm{pH}$, thus indicating its wider adaptability.

\section{Tolerance to salt concentration}

The radial mycelia growth of the isolate NRCL T-01 decreased significantly with increase in salt concentration in the PDA medium. After $3^{\text {rd }}$ day of incubation, the highest growth reduction (88.9\%) was apparent in $1.5 \mathrm{M}$ salt concentration compared to control plate (Fig. 10) followed by $1.25 \mathrm{M}(86.9 \%), 1.00 \mathrm{M}(74.7 \%), 0.75 \mathrm{M}$ (41.6\%), 0.50 M (30.6\%) and 0.25 M (19.0\%) salt concentration added to the medium. Leo Daniel et al., (2011) also reported similar results while characterizing $T$. viride for abiotic stress. Besides decrease in rate of growth, salt concentration in medium (salinity stress) also resulted in distinct changes in morphology, and a gradual reduction in sporulation with increasing concentration (Fig. 11) was observed. Knowledge of salinity tolerance and its potential effects on the antagonist will be helpful for disease management strategies.

\section{Effect of application of Trichoderma viride in controlling litchi wilt}

A talc based formulation of Trichoderma viride isolate NRCL T-01 was developed with minimum count in final product $2 \times 10^{6} \mathrm{cfu} / \mathrm{g}$. The results showed that all the potted plants having inoculation of only $F$. solani wilted in 20-30 days post inoculation, while the plants having application of talc based formulation of Trichoderma viride isolate NRCL T-01@ $50 \mathrm{~g} /$ plant plus $F$. solani did not wilt indicating the efficacy of the isolate to manage litchi wilt caused by $F$. solani. From the rhizosphere soil samples and fine root bits of wilted plants, $F$. solani was isolated on PDA medium that proves cause of wilting as inoculation with $F$. solani.
The results of the field evaluation of the $T$. viride isolate NRCL T-01 presented in Table 3 demonstrated that it effectively controlled the wilt pathogen and trees recovered in 20-35 day depending on the age and initial condition of the tree. Application of Trichoderma formulation resulted in not only $100 \%$ recovery of affected trees but also the trees regained vigour and returned to normal health (Fig. 12). The population dynamics of Trichoderma sp. in tree rhizosphere showed that at the time of application, the total count of viable prapagules were $2.10-6.67 \times 10^{3} \mathrm{cfu} / \mathrm{g}$ soils which increased up to 30 days of application $\left(30.99-60.53 \times 10^{3} \mathrm{cfu} / \mathrm{g}\right.$ soils). It is probably an important character in quick colonization of rhizosphere possibly because of the hydrolysed organic matters. This is the first report of use of Trichoderma to manage wilt caused by $F$. solani in litchi.

In conclusion, the results of the study presented in this paper is the first step in developing $T$. viride isolate NRCL T-01 as a biological control agent for managing litchi diseases especially wilt that affect trees during early establishment phase. The in vitro screening as dual culture assay showed consistent antagonism of the isolate NRCL T01 against $A$. alternata and $F$. solani. The other parameters studied such production of volatile and non-volatile inhibitors; temperature, $\mathrm{pH}$, and salt tolerance establish its fitness as a candidate biocontrol agent. The glasshouse and field studies proved its efficacy in managing wilt disease of litchi caused by $F$. solani. Additionally, the isolate showed good plant growth promotion activity acting as a biofertilizer and helping air-layers to establish better in field (data not provided). Further testing has begun to validate the potential as a commercially-viable product under farmers' field conditions. Biological control of plant pathogens by microorganisms has been considered a more natural and environmentally acceptable alternative to the 
existing chemical treatment methods. Hence, Trichoderma spp. are now the most common fungal biological control agents that have been comprehensively researched and deployed throughout the world.

\section{Acknowledgements}

The authors thank Dr. P.N. Chowdhry, mycologist and former head of the Indian Type Culture Collection, New Delhi, for confirming the identification of the pathogen.

\section{References}

Awasthi, D.P., Sarkar, S., Mishra, N.K. and Kaiser, S.A.K.M. 2005. Disease situation of some major fruit crops in new alluvial plains of West Bengal. Environ. Ecol. 23: 497-499.

Benítez, T., Rincon, A.M., Limon, M.C. and Codon, A.C. 2004. Biocontrol mechanisms of Trichoderma strains. Int. Microbiol. 7: 249-260.

Bitton, G. and Boylan, R.A. 1985. Effect of acid precipitation on soil microbial activity: I, Soil core studies. J Environ Qual 14: 66-69.

Cherif, S.S. and Benhamou, C.S. 1990. Cytochemical aspects of chitin breakdown during the parasitic action of a Trichoderma spp. on Fusarium oxysporum f. sp. radicans-lycopersici. Phytopathology 80:1406-1414.

Crane, J.H., Balerdi, C.F. and Maguire, I. 2008. Lychee growing in the Florida home landscape. Fact Sheet HS-6, University of Florida. https://edis.ifas. ufl.edu/mg051. Accessed 18 March 2016.

Dennis, C. and Webster, J. 1971. Antagonistic properties of species-groups of Trichoderma. II: production of nonvolatile antibiotics. Transactions of the British Mycological Society 57: 41-48.
Elad, Y., Chet, I. and Henis, Y. 1981. A selective medium for improving quantitative isolation of Trichoderma spp. from soil. Phytoparasitica 9(1): 59-67.

Ghildiyal, A. and Pandey, A. 2008. Isolation of cold tolerant strains of Trichoderma $s p$. from glacial sites of Indian Himalayan region. Res. J. Microbiol. 3:559564.

Ghisalberti, E.L. and Sivasithamparam, K. 1991. Antifungal antibiotics produced by Trichoderma spp. 7 Soil Biol Biochem. 23: 1011-1020.

Harman, G.E. 2006. Overview of mechanisms and uses of Trichoderma spp. Phytopathology $96 \quad 190-194$. 10.1094/PHYTO-96-0190.

Harman, G.E., Howell, C.R., Viterbo, A., Chet, I. and Lorito, M. 2004. Trichoderma species-opportunistic, avirulent plant symbionts. Nat. Rev. Microbiol. 2: 43-56.

Howell, C.R. 2003. Mechanisms employed by Trichoderma species in the biological control of plant diseases: The history and evolution of current concepts. Plant Dis. 87: 4-10.

Jash, S. and Pan, S. 2007.Variability in antagonistic activity and root colonizing behaviour of Trichoderma isolates. Journal of Tropical Agriculture 45: 2935.

Keeling, B.L. 1982. A seedling test for resistance to soybean stem canker caused by Diaporthe phaseolorum var. caulivora. Phytopathology 72:807-809.

Kubicek, C.P. and Harman, G.E. 1998. Trichoderma and Gliocladium. Vol. 1. Basic Biology, Taxonomy and Genetics, Taylor \& Francis, London. 278 p.

Kumar, K., Amaresan, N., Bhagat, S., Madhuri, K. and Srivastava, R.C. 2012. Isolation and characterization of Trichoderma spp. for antagonistic activity against root rot and foliar 
pathogens. Indian J. Microbiol. 52(2): 137-144.

Kumar, V., Anal, A.K.D., Rai, S. and Nath, V. 2017. Leaf, panicle, and fruit blight of litchi (Litchi chinensis) caused by Alternaria alternata in Bihar state, India. Can. J. Plant Pathol. http://dx.doi.org/10.1080/07060661.201 7.1401005 .

Kumar, V., Kumar, A. and Nath, V. 2011. Emerging pests and diseases of litchi (Litchi chinensis Sonn.). Pest Manag. Hort. Ecosyst. 17: 11-13.

Kumar, V., Purbey, S.K. and Anal, A.K.D. 2016a. Losses in litchi at various stages of supply chain and changes in fruit quality parameters after harvest. Crop Prot. 79: 97-104.

Kumar, V., Purbey, S.K., Pongener, A., Anal, A.K.D. and Nath, V. 2016b. Effect of some fructoplane antagonists and postharvest dip treatments on litchi fruit rots and shelf life. Int. J. Trop. Agric. 64: 333-343.

Kumar, V., Reddy, P.V.R., Anal, A.K.D. and Nath, V. 2014. Outbreak of looper, Perixera illepidaria (Lepidoptera: Geometridae) on litchi, Litchi chinensis (Sapindales: Sapindaceae)- A new pest record from India. Fla. Entomol. 97: 2229.

Leo Daniel, A.E., Praveen Kumar, G, Desai, S. and Mir Hassan, A.S.K. 2011. In vitro characterization of Trichoderma viride for abiotic stress tolerance and field evaluation against root rot disease in Vigna mungo L. J Biofertil Biopestici 2:111. doi:10.4172/2155-6202.1000111.

Limón, M.C., Chacón, M.R., Mejías, R., Delgado-Jarana, J., Rincón, A.M., Codón, A.C. and Benítez, T. 2004. Increased antifungal and chitinase specific activities of Trichoderma harzianum CECT 2413 by addition of a cellulose binding domain. Appl Microbiol Biotechnol 64: 675-685.
Lorito, M., Farkas, V., Rebuffat, S., Bodo, B. and Kubicek, C.P. 1996a. Cell wall synthesis is a major target of mycoparasitic antagonism by Trichoderma harzianum. J Bacteriol. 178: 6382-6385.

Markovich, N.A. and Kononova, G.L. 2003. Lytic enzymes of Trichoderma and their role in plant defense from fungal diseases: A review. Appl Biochem Microbiol. 39: 341-351.

N.H.B. 2016. Horticultural Statistics at a Glance 2015.Ministry of Agriculture \& Farmers Welfare, Government of India, Oxford University, New Delhi, India, p. $437 . \quad$ http://nhb.gov.in/areapro/horst_galance_2016.pdf. Accessed 121 October 2017.

Nallathambi, P., Umamaheswari, C., Thakore, B.B.L. and More, T.A. 2009. Postharvest management of ber (Ziziphus mauritiana Lamk) fruit rot (Alternaria alternata Fr. Keissler) using Trichoderma species, fungicides and their combinations. Crop Prot. 28: 225232.

Nawrocka, J. and Małolepsza, U. 2013. Diversity in plant systemic resistance induced by Trichoderma. https://doi.org/10.1016/j.biocontrol.201 3.07 .005

Papademetriou, M.K. and Dent, FJ. 2002. Lychee production in the Asia-Pacific Region. Food and Agricultural Organization of the United Nations, Office for Asia and the Pacific, Bangkok, Thailand. ftp://ftp.fao.org/DOCREP/FAO/005/AC 684e/ac684e00.pdf. Accessed 18 March 2016.

Petrisor, C., Paica, A., Florica and Constantinescu, F. 2016. Influence of abiotic factors on in vitro growth of Trichoderma strains. Proc. Rom. Acad. Series B 18(1): 11-14. 
Poosapati, S., Ravulapalli, P.D., Tippirishetty, N., Vishwanathaswamy, D.K., and Chunduri S. 2014. Selection of high temperature and salinity tolerant Trichoderma isolates with antagonistic activity against Sclerotium rolfsii Springerplus 3: 641. doi: 10.1186/21931801-3-641.

Schwarze, F.W.M.R., Jauss, F., Spencer, C., Hallam, C. and Schubert, M. 2012. Evaluation of an antagonistic Trichoderma strain for reducing the rate of wood decomposition by the white rot fungus Phellinus noxius. Biological Control 61: 160-168.

Shoresh, M., Harman, G.E. and Mastouri, F. 2010. Induced systemic resistance and plant responses to fungal biocontrol agents. Annu. Rev. Phytopathol. 48: 2143. 10.1146/annurev-phyto-073009114450

Sivan, A. and Chet, I. 1989. The possible role of competition between Trichoderma harzianum and Fusarium oxysporum on rhizosphere colonization. Phyto pathology 79: 198-203.

Vey, A., Hoagland, R.E. and Butt, T.M. 2001. Toxic Metabolites of Fungal Biocontrol Agents. In: Fungi as Biocontrol Agents: Progress, Problems and Potential. Butt, T.M., C. Jackson and N. Magan (Eds.). CAB International, Bristrol, pp: 311346.

Waseem, R., Muhammad, F., Sohail, Y., Faheem, U.R. and Muhammad, Y. 2013. Volatile and nonvolatile antifungal compounds produced by Trichoderma harzianum SQR-T037 suppressed the growth of Fusarium oxysporum f. sp. niveum. Science letters 1(1): 21-24.

Yedidia, I., Benahmou, N., Kapulnik, Y. and Chet, I. 2000. Induction and accumulation of PR proteins activity during early stages of root colonization by the mycoparasite Trichoderma harzianum strain T-203. Plant Physiol Bioch. 38: 863-873.

\section{How to cite this article:}

Vinod Kumar, Ajit Kumar Dubedi Anal and Vishal Nath. 2018. Biocontrol Fitness of an Indigenous Trichoderma viride, isolate NRCL T-01 against Fusarium solani and Alternaria alternata causing Diseases in Litchi (Litchi chinensis). Int.J.Curr.Microbiol.App.Sci. 7(03): 2647-2662. doi: https://doi.org/10.20546/ijcmas.2018.703.306 